\title{
The Metastasis of Torture: How Torture Develops In Law Enforcement Agencies In Democracies
}

\author{
Tracy Lightcap \\ Professor Emeritus of Political Science \\ LaGrange College \\ tlightcap@lagrange.edu (O) altlamp@mindspring.com $(\mathrm{H})$ \\ $706.880 .8226(\mathrm{O}) 770.444 .0842(\mathrm{H})$
}

\begin{abstract}
Most recent research on legal establishment of torture through informal institutions has concentrated on its appearance as a national policy. What has not been as extensively examined, however: is the use of torture, again justified by informal institutions, to domestic law enforcement agencies. This paper will present a beginning study of this phenomena. I will suggest a model for how informal institutions allowing the appearance of torture can become established and an hypothesis derived from it. I will then use process tracing to analyze the development of torture within the Chicago Police Department and a counterfactual case, the absence of tortuous interrogations in the Boston Police Department. Together, these cases provide a preliminary test of the model. I will conclude with a discussion of what has been learned and some speculations on how the use of torture by domestic law enforcement agencies might be prevented.
\end{abstract}

\section{Introduction}

When the Obama administration came to power it lost no time in beginning to systematically eliminate the legal and institutional bases of the torture regime the United States had used during the War on Terror. ${ }^{1}$ Within three days of inauguration orders ahd been issued to close the Central Intelligence Agency's (CIA) extensive network of secret prisons, to rescind the executive orders and legal opinions that had justified the use of "extreme interro-

\footnotetext{
${ }^{1}$ Those doubting this characterization may consult my earlier work on the subject (Lightcap 2011).
} 
gation techniques" (EIT), to close the prison at the Guantanamo (GTMO) naval base ${ }^{2}$, and to halt all proceedings of military commissions being used to adjudicate cases against prisoners at GTMO. Subsequent actions included making all of the executive orders and legal opinions concerning EIT public, successfully pushing adoption of the Military Commissions Act of 2009 that restored use of the Uniform Code of Military Justice and established new procedures for the GTMO commissions, and ordering the Attorney General to begin investigations into prosecuting those responsible for abusive interrogations for violations of the War Crimes Act. While many were unsatisfied by the scope of these actions, there was no doubt that the new administration was repudiating actions that had been central to the Bush Administration's prosecution of the "War on Terror". ${ }^{3}$

After such thorough rejection of torture at a national level, it surprised interested observers to suddenly be confronted on 24 February 2015 by a story in The Manchester Guardian (Guardian) concerning the existence of a "black prison" site at Homan Square in Chicago, Illinois. Homan Square was being used by the Chicago police force to hold persons for often torturous interrogation for varying periods before they were formally arrested and given access to usual legal procedures. The most unsettling aspect of the series of stories about the Homan Square prison was the familiar ring of the allegations to those who had studied the torture regime used in the War on Terror. One could fairly ask how this re-establishment of torture techniques at the local level could take place. Homan Square happened in a liberal democracy whose government had rejected (and still does) torture as a national policy, where the entire issue had been rehashed in an attentive, pervasive, and disapproving mass media, and where public opinion, while sometimes wavering, had disapproved of torture for decades (Miller et al, 2014).

This is not what existing research on torture would lead us to expect. In a series of pioneering studies, quantitative comparative research found that democracies are as likely to torture when under stress as autocracies (Davenport, Armstrong, and Moore 2007, Davenport, Moore, and Armstrong 2008), a disconcerting finding. Subsequent work fleshed out this picture by showing that, while the original findings on the use of torture were sustained when democracies were under stress, exposing the existence of torture when a democracy was not facing violent dissent embodied considerable risk for office-holders. The existence of periodic elections and a free press made it more likely that democratic governments would do exactly what the Obama administration did: forcibly reject torture (Conrad and Moore 2010). If this is the case, it is hard to see the mechanism that might be driving the use of

\footnotetext{
${ }^{2}$ Congressional reluctance to allow GTMO to close and resistance from the Department of Defense rendered this order a dead letter ( Brock 2016).

${ }^{3}$ The executive summary of the massive Senate investigation of CIA's use of EIT in the secret prison network released in 2014 continued this ongoing effort to eradicate torture from national policy (Senate 2014).
} 
the condemned techniques by local governments.

This paper is an attempt to answer this question. I will present an argument that will show how torture develops in local law enforcement agencies in democratic countries. I postulate that prior experience with tortorous interogations can combine with higher levels of percieved threat to the mission of law enforcement agencies to create an environment conducive to establishing torture regimes. However, the level of institutional control on officer behavior will condition this possibility. Agencies with strong institutional control over interrogations will follow official procedures and torture will not reappear. Departments without strong institutional controls, however, will develop separate behaviors with some divisions following official procedures and some creating informal institutions justifying the use of torture.

The mechanism presented in this paper will be useful for resarch purposes for several reasons. First, the arguments I give will broaden the scope of present empirical research to encompass local decisions to establish torture regimes in law enforcement agencies in democracies. As pointed out above, most research on torture has concentrated on national torture practices. There has been some research on local torture practices (Chafee, Pollack, and Stern 1969, Conroy 2000), but these studies are largely descriptive in character. Here, I attempt to provide in depth descriptions of local torture regimes tied to a theoretical framework that can help guide future analysis. Second, I will try to identify the preconditions for establishment of torture in domestic law enforcement agencies. This will include specifying the initial triggers for etablishing torture and the conditioning factors that can inhibit or ease it's adoption. Finally, I will attempt to specify the role of informal institutions in creating the space within law enforcement agencies for torture to develop. This will broaden the scope of analysis of torture by law enforcement agencies by theorizing how informal agreements to weaken institutional restraints can widen the field for illegal behavior. It will also bring the informal institutions more clearly to the attention of internal regulators in police agencies.

\section{Questions and Mechanisms}

There are two different problems concerning the appearance and sustainability of torture as an instrument of policy in democracies, but they have not received the same attention. The first involves the adoption of torture as a national policy. Here the level of analysis is the nation-state and the policies involved are either formal or informal institutions that emerge to empower torture and torturers. Here there is a great deal of research, both quantitative and qualitative, concerning the incidence and justifications of torture and tortuous interrogations. Explanations for the adoption of torture vary considerably, but are aimed at 
illuminating the motives for torture to emerge. There are two basic strains of explanation. The first focuses on problems with discipline in the armed forces and intelligence agencies due to policy changes that undermined rules enough to allow torture to develop. The second focuses on more systematic factors. Here one thread held that the asymmetric wars where official torture developed were a follow-on to a long standing tradition of oppression of colonial populations. Another, based on large-N comparative quantitative studies, presents torture as a predictable response of states under stress from violent dissent. A final theme in theses studies connects torture to the dehumanizing effects of war-particularly asymmetric war-itself. ${ }^{4}$

But, again, these studies have concentrated on only one aspect of the use of torture: its adoption as a national policy. There is a difficulty here. Perhaps the most troubling appearances of torture have been at a local level and have arisen as initiatives by local police and "order" forces. Here the question of causality becomes more complicated and the explanations more difficult. As in previous research, I postulate a model using process tracing to analyze the adoption of torture by local police and order forces (Lightcap 2011). The basic framework is displayed in Figure 1.

(Figure 1 about here)

I hypothesize that the route taken to establish torture techniques to sub-national police and order forces in democracies begins with three separate developments. The first factor to be considered is the level of prior experience. If a police force has engaged in torture as part of its usual procedurs in the past, there should be fewer inhibitions to re-establishing torture regimes as time goes on. This is in line with research on torture in democracies at the national level; scholars have found that prior experience with torture has made even democratic regimes more likely to torture at the same level when future situations replicate the past (Davenport and Armstrong 2004, Davenport, Moore, and Armstrong 2008) The second factor is the presence of a perceived threat to the local agency and its mission. The research just mentioned ties the incidence of torture in democracies to levels of violence and dissent faced by regimes (Davenport and Armstrong 2004, Davenport, Moore, and Armstrong 2008). The threat to police/order agencies is straightforward: as the level of challenges - either through public protest or increased crime and social disorder - to public order increase, the level of perceived threat increases (Davenport and Soule 2009). In turn, as levels of perceived threat increase, we would expect the possibility of establishing torture as an informal method of interrogation to increase as well.

Here the third variable in the argument becomes important: the level of institutional control in the agencies involved. By this I mean the level of consistent, clear formal regulations, internal discipline, and auditing for personnel and departmental accountability found

\footnotetext{
${ }^{4}$ For a more complete exploration of these ideas, see Lightcap (2011, 6 - 8).
} 
in the agency (North 1990). Most uniformed civil policing agencies have strong internal standards that meet these criteria most of the time. The result is that the informal practices needed for torture to develop have a difficult time becoming established. As I pointed out in earlier work, democratic citizenship is built around a recognition of individual autonomy, the equal status of citizens as part of a political community. No matter how dishonored in the breach, the equal status and dignity of citizens, at least before the law, is central to the justification of democratic states. Torture, whether used in interrogations, for prison discipline, or to suppress political opposition, obviously undermines individual autonomy. It is for these reasons that torture itself has been so rarely mandated or condoned by modern states. Even totalitarian dictatorships have denied the practice, even when its use is an open secret (Lightcap 2011, Marshall 1965). I postulate that police and order agencies with substantial levels of institutional control will stand firm against illegal practices like the use of tortuous interrogations and discipline their personnel accordingly, even when levels of threat increase. This means that the distinction between combatants and bureaucrats never arises and there is less danger of torture being established. ${ }^{5}$ The internal incentives in the local organization can hold all employees to a similar and legally sufficient standard.

But what if the subordinate agency does not have strong institutional controls? At this point some might pause. How could a police department, constrained by laws and regulatory procedures, not have strong institutional controls? Here a distinction Rejali (2006) attributes to Elio Gaspari writing about torture during the reign of the "Gorillas" in Brazil is useful. ${ }^{6}$ Gaspari distinguished between "combatants" - those soldiers or police who use torture in interrogations or have witnessed them without taking action - and "bureaucrats"- soldiers or police who are intent on maintaining normal procedures and discipline. This two-tiered system had porous borders, as Rejali points out, that made tortuous interrogations difficult to contain. The reason has to do with the third rail of institutionalization: auditing and accountability. If the law is ignored and the regulations are not enforced, then the re-emergence of torture through the establishment of informal institutions becomes more probable. Here the distinction in the model in Figure 1 becomes more plausible. What the model predicts is that if personnel migrate from positions where they have tortured or witnessed torture without action either within the local police/order agencies or in other organizations two separate tracks will develop. The first involves the bureaucrats. Since they have never embraced tortuous interrogation, they will adhere to regular procedures and

\footnotetext{
${ }^{5}$ This not to say that such departments are pristine. Police brutality-unprovoked beatings pursuant arrest or during preliminary informal interrogations - continues to be a worldwide problem and killings of civilians by police/order agencies are seldom prosecuted, usually for legal reasons (Panwala 2002). What I think is less likely in highly institutionalized departments is the establishment of torturous practices as unofficial policy within the departments themselves.

${ }^{6}$ The military governments that ruled Brazil from 1965 to 1984 were famously called this.
} 
follow the regulatory regime they find in place. ${ }^{7}$ I postulate that the combatants will take another course. The regional, decentralized nature of local police/order forces, particularly in large cities, creates space where torture can flourish as an informal institution. When combined with poor levels of institutional control, the result can be the re-creation of tortuous interrogations in special units headed by combatants. This can be accomplished using an accommodating informal institution; i.e an informal arrangement “... created by actors who dislike outcomes generated by formal rules, but are unable to change or openly violate those rules (Helmke and Livitsky 2004, 729)." Such informal institutions are based on changes in expectations for fulfilling formal rules, blurring the interpretation of rules, or undermining the norms creating presumed limits for formal rules (Lightcap 2011). The main way this would lead to a resurgence of torture is through the establishment of combatant-headed investigation units that operate secretly (or, at least, with minimal public notice) to conduct interrogations using "non-scarring" torture techniques (Rejali 2007). Of course, something like this cannot continue without complaints from those subjected to the techniques. Here is where lax auditing procedures can play a major role. If there is elite acquiescence in lax auditing, then torture techniques can be justified within investigative units as a necessary tool to combat external threats to the agency, much as has been the case for national torture regimes (Lightcap 2011). Since the interrogations are condoned implicitly by the regional elites, the accountability of the combatant teams is unlikely to lead to immediate retaliation. However, as is the case with accommodating informal institutions at the national level, a buildup of public concern can convince central elites to react by reinforcing formal rules and allowing action against the torture teams at local posts (Conroy 2000). The analysis above suggests a two part hypothesis:

H1a: If a local police/order agency has a low incidence of tortuous interrogations in the past and has strong institutional controls, then perceived threats will not lead to systematic torture developing in investigative units.

H1b: If a local police/order agency has a high incidence of tortuous interrogations in the past and has weak institutional controls, then in the presence of perceived threats informal institutions creating systematic torture can develop in investigative units headed by interrogators who are willing to use torture to counter those threats.

\footnotetext{
${ }^{7}$ This does not mean that the bureaucrats are plaster saints. See Sanders (2013) for a description of how stressful policing can be and how limits can be overstepped even by conscientious officers.
} 


\section{Data and Methods}

This is a complex set of propositions. I cannot bring them all to test in this paper. There are two main difficulties in testing the model. The first has to do with the definition of the dependent variable. The use of excessive force by police agencies has two tracks: police brutality and police torture. Police brutality usually refers to the use of excessive force by the police when conducting arrrests, restoring public order, confronting public demonstrations, or in everyday interactions with the public. The expansive nature of police work and the lack of a bight line between legitimate use of force during arrest or order keeping operations has always made a more exact definition difficult. Further, since the discretionary use of force is part of the job the police have, instances of excess are endemic for all police forces; brutality is found in every force, though not to the same degree (Bubovic 2000).

Police torture, however, is a distinct phenomena. It is systematic (i.e. intentionally adopted as a practice), affects persons already in detention, and aimed at aiding investigations by extorting confessions or to intimidate, usually those in detention but also the general public being policed (Bubovic 2000). Definiton of torture is also difficult; domestic and international law differs and this is nowhere more evident then when torture is considered. In this paper, I will be considering techniques that fall under Article 1 of the UN Convention Against Torture and Other Cruel, Inhuman, or Degrading Treatment or Punishment, regardless of whether they are legal or common practice in the police agency involved. The article defines torture as:

(a)ny act by which severe pain or suffering, whether physical or mental, is intentionally inflicted on a person for such purposes as obtaining from him or a third person information or a confession, punishing him for an act he or a third person has committed or is suspected of having committed or intimidating or coercing him or a third person, or for any reason based on discrimination of any kind, when such pain or suffering is inflicted by or at the instigation of one with the consent or acquiescence of a public official or person acting in an official capacity (United Nations 1984).

Article 16 of the Convention also bans cruel, inhuman, and degrading (CID) treatment, so there is little need to separate the two categories. Further, if the actions involved are official, intent to torture or use techniques involving CID is assumed. Since this paper specifically excludes private actions, this is a useful way to characterize the establishment of torture. Any action by a local police/order agency in a democracy that fits this definition will considered to have used torture, whether local law or practice condones it or not.

The next question to be answered before findings are presented is an empirical one: can we find cases where informal institutionalization of torture by local police/order agencies has taken place that can be used to test the model? Here the research problems become 
more difficult. The problem is the old journalistic conundrum: dog bites man is not a story, man bites dog is. It is possible to find secondary sources about police/order agencies that torture. The difficulty comes with the comparative case. Most police/order agencies do not systematically torture people, though excessive force attendant to arrest and order keeping are not uncommon. Further, there is literally no comparative data that will allow a "large N" test of the hypothesis for local agencies.

This situation calls for another strategy: the use of process tracing within particular cases. If we look for sequences within cases that track the hypothesis we can begin to address the data limitations while gathering supporting evidence. If we can find multiple instances of the test sequence of the hypothesis - interrogation units run by combatants forming informal institutions justifying torture and using it - then there will be at least prima facia evidence that the hypothesis is correct. As it happens, there is a documented case of a local police organizations in a democracy forming such units, directed by combatants, available for analysis: the Chicago Police Department (CPD) from the 1960s to the present. In the analytical sections that follow I will trace the way that torture developed in Chicago and attempt to link it to the sequences in the model. I will then present a another case: the Boston Police Department (BPD) where many of the environmental and organizational factors affecting police behavior are similar, but police torture has not developed. Including the BPD will help avoid the familiar conundrum of "choosing cases on the dependent variable"- that is, not including counterfactual examples where the proposed causal mechanisms fail to produce the predicted outcome (King, Keohane, and Verba 1994). This will not overcome the main problem wiht this analysis: a small number of cases is a small number of cases. But finding, as will be shown below, that the BPD, while similar to the CPD in many ways, has not developed similar use of police torture in its divisions presents us with a good example of what Mahoney and Goertz (2004) call the "possibility principle"; it is a case where the outcome of interest-police torture - could have occured, but did not. This will leave many gaps in the analysis, inevitable when the number of cases is limited, but an initial test of the hypothesis can be made. This will be presented in the analysis below.

\section{Informal Institutions and Torture in Chicago}

\section{Experience with Tortuous Interrogations}

The first problem faced in assessing the validity of the framework used to generate the hypotheses is presenting evidence of prior experience with tortuous interrogations. The use of excessive force by the police has been consistent thoughout history, but, as pointed out 
above, evidence of the use of police torture is usually hard to find and even harder to prove. Luckily, there is a body of evidence on this very subject covering tortuous interrogations in the United States in the early twentieth century: Chafee, Pollock, and Sterns (1969) The Third Degree. Originally the first part of the famous Report on Lawlessness in Law Enforcement made to the National Commission on Law Observance and Enforcement (the Wickersham Commission) in 1931, this report covers the use of various torture techniques to induce confessions used by police departments in the United States. ${ }^{8}$ The report includes a section on the use of the third degree in Chicago that gives us a useful benchmark for police interrogation tactics there in the early part of the last century.

Following the techniques described by Chaffee, Pollock, and Sterns, Rejali $(2007,20)$ has identified an "Anglo-Saxon modern style of torture". The basic method is built around what Conquest (1990) calls "long interrogations"; i.e. continous questionning over long periods combined with sleep deprivation, starvation, positional tortures (prolonged standing is the most usual and effective), and heat. Borrowing from US police jargon, Rejali (2007, 69) refers to this process as sweating. But the use of long interrogations also involves "softening up"; the use of non-scarring or "clean" beatings (i.e. beatings that did not leave detectable physical results) between interrogations when suspects are not cooperative. The CPD at the beginning of the 20th century had a panlopy of techniques used to physically abuse arrestees: beating with rubber hoses or straps, fists (usually to parts of the body that did not bruise easily), beating with telephone books, ${ }^{9}$ kicks and blows by clubs to the shins, suspension by handcuffs, and use of tear gas. Often state's attorneys took part in the sweating part of the interrogation. Further, suspects were often held incommunicado after arrest, sometimes for days on end, or not booked at all but subjected to long interrogations aimed at developing information on other possible suspects. Held so that their attorneys and families and friends could not locate them and in deplorable conditions, ${ }^{10}$ subjected to continous questioning and physical torture, and seeing that the prosecutors and police were cooperating in their interrogation, it is perhaps not surprising that confessions were common. All of these practices were in direct violation of Illinois law, but continued unabated in the

\footnotetext{
${ }^{8}$ The other part of the report was Unfairness in Prosecutions (1931) concerning prosecutorial malfesance. While the rest of the immense efforts by the Commission to outline in fourteen separate reports the effects and consequences the 18th Amendment on law enforcement and public law observance had very little effect, the Report on Lawlessness in Law Enforcement was a national sensation, spurring numerous efforts at reforming policing and professionalizing police departments (Walker 1997). The subsequent Supreme Court decisions in Powell v. Alabama (1932) - Walter Chafee, one of the authors of The Third Degree, represented the Scottsboro defendants-and Brown v. Mississippi (1936) have been tied in part to the additional attention to police abuses caused by the report (Keedy 1937).

${ }^{9}$ The Chicago telephone book was large and heavy even then and could be used against suspects heads effectively to stun them (Chaffee, Pollock, and Sterns 1969). This technique was also used in Iraq with the Baghdad telephone book, similarly large and heavy, as the instrument (Lightcap 2011).

${ }^{10}$ Chafee, Pollock, and Stern (1969) cite instances of 100 arrestees detained in cells at CPD stations intended for six inmates.
} 
CPD at the time The Third Degree was issued (Chafee, Pollock, and Stern 1969). And, of course, all of these practices would have been violations of the Convention Against Torture and Other Cruel, Inhuman, or Degrading Treatment or Punishment as well, had it been in force at the time. As we shall see, despite periodic efforts at reform, there have been continuities in CPD interrogation practices since the 1930s.

\section{Threat Perception}

As pointed out earlier, while there is an extensive descriptive literature concerning allegations of torture by US police agencies, there is little research at present that seeks to explain torture by them. ${ }^{11}$ Most extant explanatory research involves assessment of overall police violence and, while indirect, is suggestive concerning how to evaluate the level of perceived threat felt by the CPD. Research on levels of police violence suggest two factors that can increase feelings of threat. First, the level of violence by police agencies might be related to the level of violent crime in their jurisdictions. Obviously, the main role of police agencies is to insure public order and suppress threats to it. This role automatically puts police officers at risk: when they intervene they are most likely to be the targets of those disturbing public order and, especially, committing crimes. It would follow that the higher the level of violent crime, the more likely that the police would use force to suppress it. Research that directly addresses this idea has found that the higher the number of homicides, especially those committed during crimes, the higher the number of civilians killed by the police and the higher the level of force used in confrontations with citizens (MacDonald et al 2001, Jacobs and O'Brien 1998).

Second, there is reason to believe that the use of excessive force by police is associated with the presence of substantial minority communities. This is based on a copious literature concerning the "minority threat" hypothesis. Stemming from conflict theory, the hypothesis asserts that higher levels of social control targeted at minorities will emerge as majority populations become convinced that they are, potentially at least, under threat by minorities in their midst (Blalock 1967). ${ }^{12}$ Consequently, the minority threat hypothesis would predict that increased majority perceptions of criminal activity by minorities would foster higher levels of policing. To some extent this is understandable; minorities do commit a disproportionate amount of crime in the US (FBI 2016) However, research indicates that whites in the US tend to see minorities as having a much higher tendency to commit crime then they actually do and, consequently, support more punitive actions to control crime (Chiricos, Welch, and Gertz 2004). Further, higher levels of minority populations have been

\footnotetext{
${ }^{11}$ But see Conroy 2000 and Rejali 2007.

${ }^{12}$ The threat can be to overall power relationships or more specific personal concerns about exposure to social disorder and crime.
} 
associated with higher use of excessive force by the police (Holmes 2000, Smith and Holmes 2014). Chicago is almost a template for this situation. The city is famously segregated along ethnic lines and has had a long history, reviewed in part below, of racial tensions. Targeting of minorities by the CPD has been a long standing issue in the city (DOJ 2017). The minority threat hypothesis offers an explanation of why this is the case.

These factors are especially relevant to Chicago. The city's violent crime rate is high, but not outstandingly so. However, the number of homicides and violent crimes in Chicago is among the highest in the United States (CPD 2011, Romanyshyn 2017). This suggests that an atmosphere of concern about violent crime would develop in the CPD and the city's population, leading to a willingness to take action to reduce crime, whatever the methods involved. As can be seen in Figure 2, the number of murders in Chicago had seen a sudden and alarming increase as the 1960s ended, peaking at 970 hiomicides in 1970, a $227 \%$ increase from 1960, and leading to the city being. Since, as in all large cities, most homicides in Chicago take place in public areas, it is not surprising that public alarm over danger in the city and urgency within the CPD to combat them, reached new heights after the sudden increases in the 1970s (Wadrome 2018).

(Figure 2 about here)

The minority threat hypothesis is also relevant. Chicago is a notoriously segregated city; Acs and his colleagues consistently ranking in the top 10 of all urban areas in both economic and racial segregation of African Americans and Latinos and has seen itself become increasingly diverse in the last decades (Acs et al. 2017). As the census data shown below indicates, the white share of the population in Chicago has been decreasing apace (HHd 2018).

$\begin{array}{cccc} & \text { \%White } & \text { \%Black } & \text { \%Hispanic } \\ 1980 & 43.2 & 39.5 & 14 \\ 1990 & 38.2 & 38.7 & 19.2 \\ 2000 & 31.3 & 36.4 & 26\end{array}$

It is worth noting that the same study also found a strong relationship between homicide rates and segregation of African Americans both overall and in Chicago in particular. Since most homicides are concentrated in the West and South parts of the city - areas with high minority concentrations - and have been for some time, it is perhaps inevitable that a confluence of racial differences and high crime rates has produced, even as the composition of the CPD has adapted to more reflect the city's population, fraught relations between the police and Chicago's minorities. ${ }^{13}$

\footnotetext{
${ }^{13}$ See Hertz (2013) and, especially, Wahome (2018) for detailed visualizations of homocides in Chicago and their relationship to residential segregation in the city.
} 


\section{Institutional Control}

Like many large cities, Chicago has had a long history of grappling with the establishment and regulation of its police force. Established in 1835, the CPD followed many others in constant reorganization to meet the burgeoning growth of the city and continuous technical change. The department made many innovations - the first African American female police officer in the United States was sworn in in Chicago, the department was among the first to use fingerprint identification to investigate crimes, and the first forensic laboratory in the United States was established there - but as the city approached the 20th century problems with police corruption had greatly impeded its work. Chicago had become a major center for organized crime in the United States and a strong relationship had been built between the Mafia in the city (generally called "The Outfit") and city political and police elites (Hagedorn et al. 2013).

The CPD faced its first modern major crisis of confidence in 1960 when the so-called Summerdale scandal emerged. Eight police officers in that district had been operating a burglary ring in cooperation with professional thieves. The uproar that accompanied the discovery of the ring was the most explosive and sustained in Chicago history and resulted in the most thorough reorganization and reform effort so far attempted (Lindberg 2002). An independent four person Police Board was appointed to oversee the department and to hire a police superintendent to run day-to-day operations. But this was not the last attempt to reform the department; as O. W. Wilson, the department's first superintendent later pointed out, the problems that led to the Summerdale scandal were not successfully addressed by his administration (Hageborn et al. 2013).

Table 1 outlines the continuing crises and various reform efforts undertaken in since the Summerdale affair and attempts to connect them with on-going internal policy in the department. As can be seen, the problems with internal discipline have continued throughout the last 67 years, but administrative action to create stronger institutional controls has been limited. I believe the table establishes, however, the continuing problem the CPD has had with establishing reliable institutional controls over police behavior. This has included the emergence of the reported use of torture in two instances treated below.

(Table 1 about here)

\section{Jon Burge and Area 2}

In 1970 Jon Burge, a recently discharged U. S. Army veteran with extensive military police service, was hired by the CPD. He had served in the wars in Korea and South Vietnam. Burge volunteered twice for duty in Vietnam and was commended for his service there several times; he won a Bronze Star, a Purple Heart, and the Republic of Vietnam's Cross 
of Gallantry. His subsequent service with the CPD also led to several commendations and to rapid advancement in the department. He had accumulated several commendations from the CPD. By 1982, Burge was a lieutenant and in command of the Violent Crimes Unit in Area 2, a 60 square mile division encompassing most of South Chicago where the majority of the city's minority population lives.

Burge came to his new position in the middle of a drastic increase in violent crime in Chicago. When he took his new post, the blood letting shown ion Figure 2 had not deceased greatly; from 1979 to 1981 the number of murders remained above 800 a year, decresing slightly in 1982 (670), only to climb again in subsequent years (Bentle et al. 2018). Since most himicides in Chicago take place in public areas, it is not surprising that public alarm over danger in the city, especially in Area 2, where the bulk of the homicides were concentrated, reached new heights (CPD 2011). Soon after his appointment Burge and his unit were confronted with a prototypical crime of violence against two police officers in his area, one that immediately put the new commander at the center of attention (Conroy 2000).

On 9 February 1982, two Area 2 gang unit police officers, William Fahey and Richard O'Brien, stopped a car with two brothers, Anthony and Jackie Wilson, inside. Details are uncertain about several aspects of the incident, but, in an ensuing shootout, both officers were killed. The crime had been witnessed and descriptions of the vehicle and the assailants were available (Conroy 1990). Since four uniformed officers had been killed in Area 2 in the preceding month, finding the killers of Fahey and O'Brien was a very high priority; there were real fears that a ring targeting the CPD was operating in Area 2. Burge put his unit on full 24 hour alert and in the space of five days the Wilson brothers had been arrested and charged with the murders. ${ }^{14}$ They were subsequently interrogated, confessed, and were duly convicted for their crimes. A subsequent trial was necessary due to their convictions being vacated on appeal, but both brothers were convicted again and finally incarcerated for life (Conroy 1990, 2000, Taylor 2014).

This was all that had been heard of the Fahey-O'Brien murders until seven years later. It was then that Anthony Wilson filed a civil suit in federal district court against former Police Superintendent Richard Brzeczek, Burge, the City of Chicago, and two of Burge's subordinates alleging that his confession had been obtained through the use of torture (Taylor 2014). There was ample evidence that Wilson had been beaten while in custody - this was why his initial conviction had been overturned-but the basis for his civil suit was that he had been subjected to a wide variety of tortures while he was interrogated. Specifically, he alleged that in addition to being beaten and subjected to long interrogations, he had

\footnotetext{
${ }^{14}$ As is usually the case, the success of this manhunt depended on more on some lucky coincidences and leads from informants then the efforts of Bunge's unit. See Conroy (1990) for the details.
} 
been threatened with weapons, partially suffocated by a plastic bag over his head, burned by a cigarette and radiator, and, most tellingly, had been subjected to electric shocks to his genitals, fingers, nose, and ears by the use of an electric generator, a cattle prod, and another electric device (Conroy 2005). ${ }^{15}$ It was the use of these "extreme techniques" that had led to his (and his brother's) confession. There was physical evidence that Wilson had been tortured; the central jail refused to take custody of Wilson after his interrogation, citing his injuries. However, in his initial civil trial the defendants denied any involvement in torturing Wilson and the jury, after some deliberation, was unable to reach a verdict. As the first trial ended, however, Wilson's attorneys received anonymous tips from a police source within Area 2 that led to new evidence supporting their cause, including a new witness that had endured the same tortures and had sworn to them under oath in 1982. Further investigation led to multiple witnesses to the torturous investigations that Burge's unit had conducted. However, none of these revelations were allowed at trial and the jury, while attesting that there was evidence of a CPD policy to abuse prisoners, found that Burge and the other officers were not liable under it and that, consequently, no damages could be assessed. This ruling was thrown out on appeal and, in the interim, the Office of Professional Standards (OPS), the oversight body for police behavior, found that Wilson's allegations were sound. It also turned out that Burge had opened a second interrogation unit that had extracted confessions using slightly different torture techniques (OPS 1990) ${ }^{16}$. On recommendation form the OPS, the Police Board held hearings and fired Burge and his subordinates in 1993. Wilson's second civil trial recognized the OPS findings as probative and a summary judgment was issued, followed by a settlement. ${ }^{17}$

The exact extent of the abuses that Burge and his associates perpetrated remain in question; there are different reports of the actual number of cases. ${ }^{18}$ The pattern of torture techniques used, however, is consistent over different investigations and, in most instances, consistent with past practices. The most common allegation is that detainees were beaten, often physically or by using telephone books, but sometimes with other implements. While shocking, such tactics are not unknown in Chigago; as shwon above, most had been in use in the past. Other techniques, however, are more troubling. Many detainees were partially suffocated by having their heads placed in plastic bags. Others were subjected to hanging by their handcuffs; i.e. they were handcuffed and had their hands raised until

\footnotetext{
${ }^{15}$ The third device was probably a violet ray machine, an older version of the cattle prod now sold mostly as an erotic toy (Conroy 2005).

${ }^{16}$ There is evidence that hanging by handcuffs and choking were added by this unit, but most techniques were shared across units (OPS 1990).

${ }^{17}$ The details of this case are ably set out in Taylor (2014). This précis barely scratches the surface of the actual proceedings.

${ }^{18}$ The OPS Golston Report (OPS 1990) found 50 torture allegations from 1983 - 1986 and was able to confirm 22. The People's Law Office (2007) found 118 allegations, usually supported by sworn testimony, from 1972 - 1991. See the original reports for the different standards used to support allegations.
} 
their shoulders were under stress. Still others went through mock executions; i.e. they were directly threatened with weapons aimed at them in a way that would have caused death if the weapon was discharged. The technique that made the most impact on interrogations, however, was the use of electric shock, as described above. Use of electric shock usually led to confessions in relatively short order, if victim accounts are to be believed (OPS 1990, People's Law Office 2007). It is also worth noting that these techniques were often combined; detainees who were beaten were often subjected to some or all of these techniques as a prelude to the use of electric shocks. All of this is standard practice in torturous long interrogations (Lightcap 2011).

How did Burge's unit come to adopt these techniques? Here the evidence is strong that Burge's service in Vietnam was the source of some the torture techniques used in Area 2. There is no doubt that using electric generators (usually hand-cranked phone sets) to shock detainees was a widespread practice in Vietnam, especially among South Vietnamese intelligence and police unit. French police and military intelligence forces had pioneered the use of electric shock in Indochina before the beginning of the national liberation wars there (Rejali 2007). South Vietnamese police and intelligence forces followed the French example and continued to use electric shock in interrogations before and during the American phase of the war. US units cooperating with them sometimes took part in those interrogations (McCoy 2006). When confronted, Burge has denied vigorously under oath that he had even heard of the use of electric shocks as an interrogation technique and that he had never taken part in or observed any interrogation where it was used. However, testimony from officers and enlisted men in his unit at Ninth Infantry Division headquarters in Dong Tam confirm that the use of electric shock was well known and that US personnel had been involved in using it (Conroy 2005). No independent evidence has emerged that Burge had taken part in torture sessions during his military service. However, a comparison of descriptions of interrogations in McCoy (2007) and Taylor (2014) shows striking similarities between the techniques and sequences in his interrogations and those conducted in South Vietnam. ${ }^{19}$

But was an informal institution involved in allowing the Burge teams to torture suspects? Here the evidence is more ambiguous, but is still convincing. There had been numerous complaints about harassment and harsh questioning by Burge's unit before the arrest of the Wilson brothers and the subsequent legal proceedings that brought Burge's practices to national attention. Despite this, there was not only no criminal investigation of Burge's teams, but the complaints themselves were suppressed. Further, there were no internal investigations by the relevant CPD authorities (in this case, the OPS) until after Wilson's civil case reached federal court. The reasons for this have never been soundly

\footnotetext{
${ }^{19}$ Burge and his associates referred to their routines as the "Vietnamese treatment" in discussions with other police officers (Taylor 2014).
} 
established, but the flood of criminal confessions stemming from Burge's tortuous interrogations created a strong incentive for prosecutors to avoid questioning the Area 2 (and, later, Area 3) interrogations. That many of the suspects in these cases were admitted felons with extensive criminal records - the very kind of suspect creating the social disorder the department feared - no doubt also played a role. The slow unraveling of the silence maintained around Burge's teams actions was also sustained by another circumstance in Chicago politics. Members of the prosecutorial staffs responsible for accepting the coerced confessions and conducting trials based on them often used this record to ascend to the bench in Cook County or to city-wide elected office. The most prominent of these was the State's Attorney who received (and buried) the complaints from Area 2, Richard M. Daley, who followed his father's footsteps to become Mayor of Chicago. By the end of the lawsuits involved, there was general recognition by legal authorities that a general conspiracy existed to both protect the torture regime in Area 2 and to shield those who had done the protecting. As Judge Milton Shadur put it,

It is now common knowledge that in the early to mid-1980s Chicago Police Commander Jon Burge and many officers working under him regularly engaged in the physical abuse and torture of prisoners to extract confessions. Both internal police accounts and numerous lawsuits and appeals brought by suspects alleging such abuse substantiate that those beatings and other means of torture occurred as an established practice, not just on an isolated basis (Taylor 2014, 352).

This fits Helmke and Levitsky's description of an accommodating informal institution: the interpretation and limitations of formal rules and norms are blurred or undermined in order to achieve goals stricter adherence to formal rules would not allow. There is another aspect of this that indicates the presence of informal institutions: the response of elites to the revelations. As Helmke and Levitsky point out, one reason that informal institutions come into existence is that it is easy to repudiate them once they are discovered (Helmke and Levitsky 2004). Conroy (2000, 244 - 247) has a useful listing of the ways that the discovery of torturous interrogations are "handled" when they are exposed. A variety of the defenses he mentions were offered concerning the Area 2 abuses: the distinguished records of Burge and his subordinates were cited, the extent of the abuses denied, the victims were castigated, the lawyers who pursued the torture teams were disparaged, and, finally, the entire episode was blamed on Burge and the "bad apples" who operated under him. ${ }^{20}$ On top of all of this

\footnotetext{
${ }^{20}$ Each of these techniques is described in Taylor's (2014) comprehensive overview of the litigation that arose from Burge's activities. See Taylor (2014, 333) or Conroy (2000, 229) on how Burge's reputation helped protect him. Also, see Taylor $(2014,336)$ on denial of the extent of abuses, Taylor $(2014,335-36)$ on how the victims's records were used to undermine their complaints, Conroy $(2000,164-67)$ on how the plaintiff's lawyers in the original civil case were handled, and Tylor $(2014,341-42)$ on the attempt of the City to deny liability due to Burge and his subordinates acting beyond their scope of duty. That Burge's units had obtained a sterling record of confessions from career criminals also had the effect of lining the state's attorneys office he dealt with strongly behind him (Taylor 2014).
} 
was the City's constant use of settlement as a tool for protecting higher ranking officials from testifying under oath; by 2014 Chicago had paid out $\$ 64.1$ million in settlements rising from cases involving torturous interrogations by Burge and his associates, much of it to forestall testimony by city officials (Taylor 2014). Finally, there was little notice in Chicago media at first; it took years of trials and settlements with Burge's accusers, multiple official city and state investigations confirming the use of torture and CID in Area 2, and Burge's own federal conviction for perjury to bring his actions into the public spotlight (Spinner 2015). The stonewalling by Chicago police and government elites worked.

\section{Richard Zuley and the Homan Square Isolator}

Given the extensive and public exposure Chicago had undergone in the Area 2 cases, it was a surprise to many when the 24 February 2015 US edition of the Guardian, broke a story alleging that the CPD was operating a covert prison at the Homan Square warehouse. Homan Square is the headquarters of the CPD's vice, narcotics, and intelligence units and, understandably, has been operated under high security for a civilian police facility (Ackerman 2016). What the Guardian revealed, however, is that the warehouse has been used for years as a temporary holding facility that keeps detained suspects out of CPD booking procedures for periods of up to a week. ${ }^{21}$ During that time, their location is unknown, kept secret from their families and attorneys. Suspects detained at Homan Square can then be questioned without counsel present and using techniques involving both torture and CID to both extract information and pressure detainees to become police informants (Ackernam 2015a, 2015b).

Homan Square is an "isolator"; i.e. a prison or part of a prison separated from regular internment so that prisoners can be interrogated or subjected to special punishment regimes off record in isolation from other inmates and from outside help. The most famous contemporary example is Abu Ghraib prison outside Baghdad. Most to the prisoners at Abu Ghraib were housed inside the prison walls in tents. However, within the prison there are two cell blocks (1a and 1b) where prisoners of particular interest for intelligence purposes were housed. It was in the cell blocks that the tortuous interrogations at Abu Ghraib took place (Jones and Fay 2004). ${ }^{22}$ Similarly, prisoners at Homan Square are held inomunicado and separate from the usual precinct lockups used for most suspects before they are transported to the Cook County Jail. The period of detention was usually one day or less, but, in some cases, lasted up to a week. During this incommunicado period, prisoners were interrogated and, in many cases, pressured to become CPD informants. Indeed, some detainees have

\footnotetext{
${ }^{21}$ Again, this recalls previous methods used by the CPD (Chaffee, Pollock, and Stern 1969).

${ }^{22}$ This is not a new idea. It was extensively used by the Soviet Union - the Lubyanka and Lefortovo prisons were isolators - and is also common in US state prison systems. Cell blocks C and D at the Pelican Bay "supermax" prison in California are a primary example (Solzhenitsyn 1973, Cannon 2016).
} 
maintained that they were never actually arrested or charged; they were instead picked up on the street by undercover police officers, taken to Human Square, abused until they agreed to help the police charge others, then released (Ackerman 2015a). Consequently, criminal defense attorneys in Chicago have long since assumed that when they cannot get information about where their clients are held they are probably at Homan Square and that they will be denied access (Ackerman 2015a, Basu 2015 ). ${ }^{23}$ Further, an Illinois FOIA lawsuit has revealed that Homan Square was used extensively by the CPD; from late 2004 through 2015, 7185 arrested persons were detained there without booking information, almost all of them (82.2\%) African-Americans arrested for drug offenses. Of those detained in this period, 64 were granted access to their attorneys while at Homan Square (Ackerman 2015a).

Some of the techniques used at Human Square - depriving detainees of bathroom breaks, for instance - are standard interrogation practices in police organizations everywhere. However, other torture and CID techniques are alledged to be used to insure compliance, similar to those used in torturous interrogations in Iraq and Afghanistan. While there were different techniques used on different detainees, all were subjected to shackling with either handcuffs or "flex-cuffs" to walls within either small cells or wire enclosures like those at Guantanamo Bay prison. ${ }^{24}$ Some were shackled in "stress positions" that made movement difficult or rendered them helpless to beatings. Others were deprived of food and water during their incarceration. There are 14 documented cases of use of a variety of physical actions detailed in CPD "Tactical Action Reports". Other allegations include temperature manipulation in interview rooms, threats against family members, anal sexual assault, tasering, and strangulation with a flex-cuff (Ackerman 2015b, Ackerman 2015d) ${ }^{25}$ Finally, there has been one questionable death in custody (Stafford and Ackerman 2016). All of these allegations were reviewed by the Independent Police Review Authority and exonerated the officers involved. On-going lawsuits may reveal more and sort out how well established the allegations are as the record matures.

(Figure 3 about here)

In related articles, the Guardian also revealed that another CPD officer, Lieutenant Richard Zuley, had embarked on a course of torturous interrogations for almost as long a

\footnotetext{
${ }^{23}$ It is difficult for attorneys to get access to clients in CPD custody at precinct houses, especially directly after arrest. Still, if their clients are booked at the precinct, they can get to see them within a few hours. It is just this kind of contact that is almost impossible to get at Homan Square (Ackerman 2015a). Again, these practices copy those used by the CPD in the early 20th century (Chafee, Pollock, and Stern 1964).

${ }^{24}$ It is normal police practice to use handcuffs to take suspects from holding cells to interview rooms or to move them within and between stations and jails. However, continuous shackling, keeping suspects in handcuffs during interrogations and throughout their detention, most definitely is not a standard practice (Ackerman 2015b).

${ }^{25}$ For parallels in torture practices in the War on Terror, see Lightcap (2011, 18 - 25). Some of the shackling episodes described are equivalent to "short shackling"; i.e. shackling detainees in ways requiring distortions of the body equivalent to stress positions.
} 
period as Burge before him. Like Burge, Zuley had been commended and promoted for his ability to produce confessions. Subsequent examinations of his records, however, revealed that between 1995 and 2007 he had often coerced confessions from suspects. Unlike Burge, however, Zuley had used techniques more reminiscent of recent practices: prolonged shackling, stress positions, isolation, and threats against family members (Ackerman 2015c) ${ }^{26}$ In one instance post-conviction review has led to the release of one of those convicted as a result of Zuley's interrogations (Ackerman 2015c). While no connection has been made between Zuley and interrogators at Homan Square the parallels in practices between the prison and the detective are striking.

Again, the question of informal institutions arises. The record for Human Square and for Zuley's actions is much less well developed that that for the Area 2 abuses, but responses to the initial revelations have been similar. As before, civil lawsuits concerning the coercion of confessions and the use of torturous techniques at Homan Square emerged. As in the early stages of the Area 2 investigations, the CPD has issued blanket denials of all allegations against officers at Homan Square. The usual response to the plaintiffs in the suits involved has been that all allegations of abuses have been investigated by the Independent Police Review Authority and that the officers involved have been exonerated, as is indeed the case. Local media, as was the case with Area 2, have been largely silent about both Homan Square and Zuley's career (Spinner 2015). It remains to be seen if further developments will yield the same stream of revelations that accompanied the earlier Area 2 scandal will emerge.

\section{Formal Institutions and Interrogations in Boston}

\section{Experience with Tortuous Interrogation}

Boston can claim to have had a police force longer then any other municipality in the United States, beginning with the city watch in established in 1631. The modren Poston Police Department (BPD) wqas established 1854. As in Chicago, the research effort in The Third Degree covered police practices in Boston. However, their findings were radically different. The BPD had not used tortuous interrogations. There were sustained allegations of holding suspests incommunicado and questionning them at precinct staions after arrest, but before central booking took place. Further, the BPD, in common with many police agencies had had problems with assualts during arrest and transport to stations. What was defnitely missing, however, waa any evidence of long interrogations using beatings or other tortuous

\footnotetext{
${ }^{26}$ Zuley shackled suspects in handcuffs for periods of over a day and, when he did not get confessions, tightened the handcuffs after each unprofitable interrogation. Coincidently, Zuley, who was a naval reserve officer, was also an interrogator at the Guantanamo Bay Prison where he used similar techniques on detainees there (Ackerman 2015c).
} 
techniques (Chaffee, Pollock, and Stern 1969).

The reason these practices had not taken root in Boston had to do with the institutional controls in place, command policy, and community acceptance. Massachusetts had (and has) quite strict laws, diligently enforced by the courts, requiring speedy production of suspects before magistrates after arrest. Criminal laws forbidding the use of toruous techniques in interrogation were also in existence and strictly enforced. ${ }^{27}$ In part, this is because judges in Massachuestts courts then and now and the Commissioner in charge of the BPD (until 1962) were appointed by the Governor of the state and fiercely independent. Further, two of the first three appointed Commissioners served long terms and were known for intolerance for breaches of discipline and tortuous interrogations. ${ }^{28}$ Finally, unlike in Chicago, Boston did not have a Mafia family or much in the way of organized criminal "crews" in the 1920s (it most definitely does today) and the kinds of infiltration found in the CPD did not exist. With the press firmly behind holding the BPD responsible for even minor abuses, the public atmosphere described in The Third Degree was singularly unaccapting of tortuous interrogations and physical abuse by the BPD (Chaffee, Pollock, and Stern 1969). One could hardly ask for a more complete contrast to the Chicago experience.

\section{Threat Perception}

Boston's rate of violent crime has been not particularly high. Like Chicago, however, Boston has also suffered an increase in the number of murders that led to public concern. Figure 3 compares the number of murders in Chicago and Boston for the approximately the last 60 years. As can be seen, Boston had a sudden increase in homocides as the 1960s ended,; indeed, the percent increase in these crimes-from 1960 to 1975 it was 435\%-was greater then in Chicago. Chicago population has been roughly 4.5 times that of Boston during this period, but notice that the total number of murders in Chicago is almost an order of magnitude higher at all points. ${ }^{29}$ Further, efrorts by the BPD in the 1990s led to the "Boston Miracle"; a drastic reduction in murders that has continued to the present. In short, the level of tension over violent crime in Boston, while not negilible, is not at the same level found in Chicago.

(Figure 3 about here)

As in Chicago, Boston is a city with racial tensions. Measures of segregation of minority

\footnotetext{
${ }^{27}$ Massachusetts law also allowed individual police officers to be sued civilly for physical abuses of any kind.

${ }^{28}$ The first of these, Stephen O'Meara, established this tradition. O'Meara, a former police reporter and later editor of the Boston Globe, was particularly inolerant of abusive interrogations. His close successor, Edwin Custis, had shared his abhorence for tortuous interrogation or, for that matter, any breach of discipline (Chaffee, Pollock, and Stern 1969). It was Custis who broke the 1919 Boston Police Strike and established the national precedent that public safety personnel could not strike.

${ }^{29} \mathrm{Aw}$ with Chicago, all of these statistics are for the city proper, not the metropolitian areas (HHD 2019).
} 
communities in the city are consistently among the top ten cities in the United States, but the level of separation in Boston has been much lower over time then in Chicago (Glaeser and Vigdor 2012). Violent crime is also concentrated in minotrity areas in Boston, but was never as high as found in Chicago in either rates or total numbers and has decresed greatly in recent years $<$ cites $>$. Also, as in Chicago, census data indicates that the share of the white population in the city is decreasing, though not as percepitiously as in Chicago (HHD 2019).

$\begin{array}{cccc} & \text { \%White } & \text { \%Black } & \text { \%Hispanic } \\ 1980 & 67.9 & 21.7 & 6.4 \\ 1990 & 59.1 & 24 & 10.4 \\ 2000 & 49.5 & 23.8 & 14.4\end{array}$

In short, the level of minority threat in Boston is likely to be lower then what is found in Chicago, despite the similarities of the cities otherwise.

\section{Institutional Control and Interrogations in Boston}

Like Chicago, Boston has had a long history of grappling with the establishment and regulation of its police force. Since establishment in 1854, the BPD also faced constant reorganization to meet a growing and diverse population. However, as pointed out above, the BPD fell under the control of a series of long-serving commissioners who constantly enforced a regime of tight regulation of police behavior. Even after organized crime made major inroads in the city, the major instances of infiltration of law enforcement were, paradoxically, in federal law enforcement, not the BPD. Table 2 outlines the major crises and reforms established since the early 1960s. It is illuminating to see that most of these efforts stemmed from marginal breakdowns in policing, not the kind of unbridled criminal police activity outlined in Table 1.30

(Table 2 about here)

The only evidence of alleged tortuous interrogations in recent BPD history was in connection with the notorius Charles Stuart murder case. In October 1989, Charles Stuart phoned the BPD and reported that he and his pregnant wife Carol had been accosted and shot. Carol Stuart died in a few hours and her child, delivered prematurely, died 17 days later. Subsequently, Stuart identified their attacker as a young black male. The BPD immediately turned Mission Hill, the diverse neighborhood where the supposed murders had takens place, upside down. Intensive Terry searches of all young black men on the streets brought immediate outcries from some minority community leaders, but were accepted by

\footnotetext{
${ }^{30}$ This is not to say that the Boston police have a pristine record concerning the use of excessive force. The department has had continuing problems with public and judicial concern over the use of force in public confrontations and arrests (see Billis 2016, Commonwealth v Thomas Adams 1993 as examples).
} 
others. ${ }^{31}$ This soon led to the police focusing on a known Mission Hill thief, William "Willie" Bennett. Soon after Bennett was arrested Stuart's younger brother Matthew came to the BPD with evidence that his brother might have been murdered his wife. Charles Stuart, rather then face the charges he knew were coming, committed suicide (Scalese 2014).

The ensuing uproar by a now throughly aroused minority community and an abashed white one, led to a major investigation by the Civil Rights Division of the Massachusetts Attorney General (hereinafter the Shannon Report) and examinations of BPD search procedures by blue ribbon advisory committees (Office of the Attorney General 1990, Supreme Court Advisory Committee (the Hennessey Report) 1990, Boston Police Department Management Review Committee (the St. Claie Report) 1992). All of these bodies recommended changes in search procedures and BPD training. The Shannon Report included and expanded on many of the questionabale searches. However, it also included evidence of abusive interrogation of several of Bennett's associates by the BPD. Specifically, Deputy Attorney General Shannon alleged that the BPD had questionned two juvenile aquaintances of Bennett-Dereck Jackson and Eric Whitney - for several hours. This would not be unusal, but the witnesses were also threatened with imprisonment, with beatings by one of the officers, and in one case with brass knuckles worn by the same interrogator. ${ }^{32}$ One was refused an attorney when he requested one as well. To stop the questionning and appease the officeres, two of the young men fabricated testimony implicating Bennett. But both young men were released that day and after discussing the epiosde, decided to retract their testimony. After a subsequent round of questionning, however, they agreed to implicate Bennett again and testifued against him to a grand jury hearing the case. Both retracted their tesitmony later. All of this was corrobrated by other witnesses. Other young people and two adults were also questioned and threatned with imprisonment if they did not implicate Bennett, but none of them agreed to do so.

The Shannon Report is disturbing and the allegations against the officers were serious; they involved clearly unconstitutional actions that would have fallen under the UN Torture Convention as well. However, nothing alleged approached the long interrogations used by Burge's unit in Chicago or the accounts concerning Homan Square. The interrogations, while threatening, did not involve prolonged "sweating"; there was no use of sleep drprivation, no thirst or starvation, no stress positions, and no serial interrogation. Indeed, the young men were released to go home as soon as they implicated Bennett and they recovered their equilibrium relaitvely quickly. There were no clean beatings, no use of electric

\footnotetext{
${ }^{31}$ Terry $v$. Ohio (1968) and its progeny have greatly loosened exsisting constraints on police searches pursuant to possible arrest $<$ cite $>$.

${ }^{32}$ The officer in question, Willima Dunn, had roughed up one of the young men on the street before and had a neighborhood reputation (Civil Rights Division 1990). It should also be noted that Jackson had an outstanding criminal matter standing against him; the threat of imprisonement for lack of cooperation in his case was quite real to him.
} 
shock, no short shackling (indeed, no shackling at all), or any of the other techniques used by the Chicago combatants. Further, far from being protected, all the office involved were charged with misdemeanrs, although the state charges were finally dropped due to insufficient evidence (Office of the Attorney General 1991). In short, the establishment of informal institutions supporting tortuous interrogations was never even attempted in Boston, despite a general public panic over a notorious dual murder in a city with a history of racial tension. The overall formal and informal constraints on police interrogations esatblished in the past in Boston and sustained in the present - the actions taken after the Stuart case showed them very much in force - were not enough to prevent the use of coercion in interrogations completely, but they sufficed to prevent sustained and egregious abuses.

\section{Discussion}

The pattern of evidence given above is by no means conclusive proof of the hypotheses. The largest lacuna is the lack of a demonstration that "bureaucrats" in agencies with weak institutional controls will not turn to torture and CID techniques, a crucial aspect of H1b. Indeed, a data collection effort to get the personnel records that would test this part of the paper's propositions or those concerning H1a and solidify the paper's speculations about the use of torture in subordinate units would face substantial legal barriers. Further, efforts to collate complaint data with personal backgrounds of officers over a 40 year period would be formidable. Despite these shortcomings, however, the findings above are at least suggestive in support of parts of the hypothesis.

The Chicago case I have presented here is a combination of what Collier (2011) calls straws in the wind and smoking gun tests. Chicago meets the criteria for background conditions for operation of the hypotheses. The level of perceived threat for the CPD can be considered high due to the high numbers of violent crimes, particularly murders, and the presence of substantial, increasing, and segregated minority populations. Further, the CPD and Chicago's political leadership have had continuing difficulty in maintaining institutional control over the department. Given this, I suggest that the Area 2 case presents the smoking gun. As Collier explains, the so-called smoking gun test is met when there are sufficient

grounds for accepting an hypothesis, but not necessary ones. The sequence of events in Area 2 meet these criteria well. The basic requirements of the overall model are met well and the behavior of Burge's units fits closely with the H1b. There is evidence that the techniques he used in interrogations were well known to fellow officers and to the state's attorneys he worked with, but were deemed both useful for obtaining confessions that closed cases and for combatting Chicago's violent crime problem. The lax discipline in the CPD and the eagerness of the State's Attorney (and Burge; his reputation was enhanced) for convictions 
combined to produce a protective shield based on a shifting of norms of interrogation around Burge. There was little outside or inside investigation of the allegations until the second Wilson trial (Taylor 2014). ${ }^{33}$ In other words, there is sufficient evidence, legally recognized, that informal institutions developed that allowed a torture regime to flourish in Area 2 during Burge's tenure there. Further, the pattern of repudiation of those informal institutions closely follows Helmke and Levitsky's (2004) framework. Once the extent of abuses had been revealed and strong evidence about them had accumulated, the entire arrangement was publicly repudiated by Chicago authorities, though the flexibility to reestablish the informal norms was maintained by the lack of action to tighten institutional controls on the use of either torture or CID techniques.

On the other hand, the Homan Square and Zuley cases are, at best, a straw in the wind, presenting neither sufficient or necessary grounds for accepting the hypothesis, but also generally fitting the causal sequences it proposes (Collier 2004). For these two instances, the record is undeveloped and the actual sequence of events is uncertain. It is evident that both personnel at Homan Square and Richard Zuley used torture and CID techniques similar to those used at multiple sites in the Middle East and at Guantanamo Bay during their interrogations However, there has not been no evidence of a connection between the torture techniques used at Homan Square to those used in the War on Terror; only Zuley's service at Guantanamo makes that linkage and he has not been shown to have worked with interrogators at Homan Square. Further, it has not been determined how extensive the abuses at the prison were or when they started. Finally, while the responses of the CPD, Chicago city government, and local media show similarities to what emerged early in the Area 2 scandal, the current situation is only indicative. In short, the second case does not prove or disprove the hypothesis, but rather gives it weak support that warrants further work.

However, the combination of both cases is highly suggestive. There are three reasons I assert this. First, consider the time frame of the two cases. Burge's units in Area 2 had been active throughout the 80 s and by the early 90 s their practices had become a widely known public scandal. Despite this, Homan Square developed and Zuley adopted torturous interrogations a decade later. Obviously, the salience of the Area 2 affair did little to change the incentives to negate torture. In other words, the robustness of the mechanism proposed in this paper is supported as much by the sequence of the cases over extended time as by their content. Second, the techniques involved in interrogations in both cases track both the past experience of the CPD and the experience that the perpetrators had with successive torture regimes at higher levels. Recall that the Area 2 units were headed

\footnotetext{
${ }^{33}$ Later, in Area 3, when Burge was promoted to chief of detectives there, similar allegations surfaced and were similarly ignored until the weight of evidence made maintaining the facade impossible (Taylor 2014).
} 
by an officer who, despite his denials, probably had either participated in or heard accounts of torturous interrogations in South Vietnam. The techniques used in those interrogations, particularly electric shock, followed practice during the American phase of the Indochina War. What is most interesting, however, is how practices used in interrogations at Homan Square and by Zuley track the "non-scarring" techniques popularized in US practice by the interrogations in Iraq and Afghanistan and at Guantanamo Bay prison. In this case we have confirmed participation in tortuous interrogations; Zuley was in change of the interrogation of Mohamedou Ould Slahi at Guantanamo, specifically singled out in the Schmidt-Furlow Report (2005). Further, he is mentioned by name in Slahi's memoir of his interrogation (Ackerman 2015c). Again, the sequence is what is revealing here; the torture and CID techniques used in interrogations justified by informal institutions at the national level were recapitulated at the local level in Chicago and supported any informal institutions there. Finally, there are the similarities in the justifications and functions of informal institutions in the two cases. In both cases, the initial response has been to simply deny that anything untoward has occurred. This is the response of the CPD, of elected officialdom, of some of the legal community, and of mass media in Chicago and was the response during the Area 2 scandal (CPD 2015, Durkin 2016). There is an opportunity here as the record on Homan Square and Zuley matures. If the pattern of the pending civil lawsuits follows the development of the Area 2 cases, we should see more specific, time relevant information on how interrogations have been conducted, the establishment of connections between Homan Square and practitioners of non-scarring torture and CID techniques, and more allegations will surface. If this does not develop, then the second case will no longer support the hypothesis and the analysis in this paper will be less convincing.

The lack of developnent of informal institutions in Boston is also consistent with the model, but the evidence here is less strong. As might be expected, the scandals that surround the Chicago torture units have provoked an extensive research efrort in that city aimed at uncovering further abuses. The large number of court cases has also provided a substantial record of Chicago's experience with police torture. The record is much less strong in Boston. There is no public evidence that units of combatants worked there in the past or today, but that is not sufficient for our purposes here. Again, the substantial problem of tracing police personnl actions and disciplinary proceedings intervenes. Further, the "blue wall" is in evidence in Boston as in Chicago; the Attorney General's auhtority coud not shake it during the investigation of the coercive interrogations (Office of the Attorney General 1990). The absense of any further relevations may be a matter of abuses covered up; the St. Clair Report (1992) was scathing in its dunnunciation of the lack of menaingful internal affairs investigations in the BPD. The ensuing reforms appear o have allevuiated this problem, but doubt should linger. 
For all that, however, the findings concerning Boston do constitute at leat a straw in the wind in support of H1a. It is not proven - two cases cannot be considered proof for any hypothesis - but Collier's (2004) criteria are met. While the record in Boston is neither necessary or sufficient to provide strong evidence for H1a, it does fit the general pattern outlined in the model for such cases. Boston had no history of torturous interrogations in the past and had strong leadership that condemned the practice in the early 20th century. Like Chicago, the city has become more diverse and, at the same time, remains highly segregated. Again, like Chicago, it experienced sudden spikes in violent crime in both the $70 \mathrm{~s}$ and $90 \mathrm{~s}$. There is little evidence that this led to an unmooring of the institutional constraints on police interrogation that led to the development of informal institutions protecting combatant units within the BPD. Evne in the face of a sensational crime that led to widespread panic and concern in the city, the level of perceived threat never reached levels to overwhelm the BPD's discipline completely (Scalese 2004). The coercive interrogations alleged in the Shannon Report (1990), while unconstitutional and illegal under both federal and Massachusetts law, never approached the extremes found in Burge's Area 2 and Area 3 units, or at Homan Square. The restraints on the BPD were sorely tested in 1989, but stopped torture at the threshold successfully.

\section{Conclusions}

On 13 January 2017, the Department of Justice (DOJ) released a comprehensive report on a year long investigation into the CPD (DOJ 2017). The investigation centered around the need for the CPD to establish relations of trust with Chicago's minority communities on its South and West side. It was the DOJ's contention that the surge in shooting and homicides in Chicago in 2017 was the result of an incapacity of the CPD to adequately police those communities. The report concluded that the CPD needed improvement in several areas:

- The DOJ found that the officers routinely used force, including deadly force, in ways that violate both CPD policy and citizen's rights. In particular, the report found that the lack of clear policy guidance on the conditions for using force and lack of investigation into complaints involving excessive force.

- The report also found that the oversight of the CPD was lax and fostered an atmosphere of license among its officers. Part of this was due to lack of investigation of many incidents, lack of followthrough by the IPRA (only $2 \%$ of 3000 citizens complaints from 2012 to 2017 had been sustained), lack of investigative personnel and training for the IPRA, and a "code of silence" among CPD officers that undermined investigations of all sorts in the department. The new Civilian Office of Police Accountability that 
replaced IPRA in 2017 has a broader mandate, but no more resources to face these challenges.

- Training for CPD officers is outmoded and too often focuses on problems other then use of force. Further, the CPD has a serious shortfall of field officers who can train probationary officers. The lack of supervisors and the many administrative tasks they are given makes serious oversight of officers sporadic at best.

The report also targets other areas of concern but in terms of this paper, the DOJ's case against the department on the use of force and lack of accountability provides independent collaboration of both the lack of institutional control postulated in the model and the shifting of norms and policies that are conducive to the formation of informal institutions. The torturous interrogations in the Area 2 and Homan Square cases followed as "combatants" took charge of investigative units in the CPD, with the cooperation of those who should have been restraining them.

The question of how to avoid the sequences proposed in this paper remains. At present, this is an indeterminate matter. As was pointed out above, the data is no more than suggestive that the hypothesis of the paper is correct. The evidence is not in and, given the problems with data collection mentioned above, may never be. The DOJ report focuses on the need to address problems with the use of force across the board: better policy, better accountability, better training, better oversight. No doubt emphasis in these areas would improve the situation. The question, however, is whether following through with the DOJ's recommendations would reduce the chances of more unit based torture regimes in the department. Here the problem of effective policy to reduce human rights violations surfaces. As Celermajer and Grewal (2013) point out, there are plenty of courses of action recommended to reduce torture by police agencies, but the connections between actions taken and results achieved are seldom made. Instead, there is an assumption that correct standards for interrogation and emphasis on them will lead to a reduction in torture. ${ }^{34}$ The dearth of useful research on how interventions actually work to reduce human rights violations makes attempts to control such depredations problematic. Celermajer and Grewal, citing their own experience, call for extensive preliminary research on the context of torture in the organizations concerned and in the culture the organizations work in. This would then be followed with an assault on human rights violations on many fronts, not simply as a matter

\footnotetext{
${ }^{34}$ This is a common problem in legal institutions. In my own experience, I have found that often the assertion of correct behavior by legal agents is deemed sufficient to change practices. Hence the proliferation of "standards" in evaluations of courts and police departments. The usually unspoken assumption is that the sanctions in the law or in organizational hierarchies will prove sufficient to change what people are doing. The lack of evaluation built into the introduction of interventions in policy is part of this; why evaluate when those who violate the new policies are subject to penalties? As this paper has tried to point out, such a strategy is unlikely to be successful when informal institutions justify behavior that contradicts policy.
} 
of the right training. The DOJ's recommendations foresee such a strategy in Chicago, but are lamentably short on practical advice on how to accomplish their goals.

Unfortunately, the Boston case highlights further the difficulties in correcting the incidence of police torture. What seems to have happened in that city is that opposition ot the third degree in the past combined with lower oevels of perceived threats has created an institutional atmosphere that, while accepting of the sometimes excessive use of force in arrests and public confrontations, has stood fast against it in interrogations. When the capability of governments or other social agencies to change the inheritance of the past and the lack of knowledge about how perceived threats to social order emerge or develop are considered, the prospects for successful action to curb tortuous interrogations remains as doubtful as Celermajor and Grewal say. The impersonal forces involved have often defeated policy interventions. Only subsequent research and a stringent effort to consider context when conducting it seems likely to suggest avenues for intervening in the mechanisms I have proposed here. That, if others are at least partially ocnvinced by the model I have proposed, should be the next mission for researchers in htis vital area of concern for human rights.

On 13 December 2017, Chicago Sun-Times reported that two inmates convicted of murder after an investigation by retired CPD detective Reynaldo Guevara had had their confessions thrown out because the judge in the case deciding that Guevara, despite being given immunity, had lied on the stand in his trial when he denied his role in framing them. The inmates alleged that Guevara had beaten and threatened them into confessions, a pattern also reported by others that had been convicted on the basis of investigations conducted by Guevara (Grimm 2017). It is obvious that the problems in Chicago continue. Despite Mayor Rahm Emmanuel's pledge of $\$ 27.4$ million dollars to police reform in the city, the recent decision of the DOJ to release Chicago from a planned consent decree mandating court monitoring of the reform effort puts further progress at risk. If the city decides to continue its reform of the CPD, I hope that the patterns revealed in this paper, however speculative, might help both Chicago and other police agencies to see how torture and CID can emerge in interrogation practices in democracies and lead to research that can suggest ways to short-circuit the process.

\section{References}

[1] Ackerman, Spencer. 2016. "The Hidden: How the Chicago Police Kept Thousands Isolated At Human Square." https://www.theguardian.com/usnews/2016/apr/13/homan-square-chicago-police-records-secret-interrogation-facilitynew-documents-lawsuit (March 8, 2018). 
[2] Ackerman, Spencer. 2015a. "Chicago Police Detained Thousands of Black Americans At Interrogation Facility." https://www.theguardian.com/us-news/2015/aug/05/homansquare-chicago-thousands-detained (March 9. 2018).

[3] Ackerman, Spencer. 2015b. "'I Was Struck With Multiple Blows': Inside the Secret Violence of Homan Square." https://www.theguardian.com/us-news/2016/apr/11/homansquare-chicago-police-internal-documents-physical-force-prisoner-abuse (March 10, 2018)

[4] Ackerman, Spencer. 2015c. "Bad Lieutenant: American Police Brutality, Exported From Chicago to Guantanamo." https://www.theguardian.com/usnews/2015/feb/18/american-police-brutality-chicago-guantanamo (March 9, 2018).

[5] Ackerman, Spencer. 2015d. "Homan Square Detainee: I Was Sexually Abused By Police At Chicago 'Black Site." https://www.theguardian.com/usnews/2015/may/14/homan-square-detainee-police-abuse (March 9, 2018).

[6] Basu, Tanya. 2015. "Behind 'the Disappeared' of Chicago's Homan Square." The Atlantic, 24 February.

[7] Blalock, Hubert M. 1967. Toward a Theory of Minority-Group Relations. New York: Wiley.

[8] Bruck, Connie. 2016. "Why Obama Has Failed To Close Guantanamo." The New Yorker, August 1 .

[9] Cannon, Gabrielle. 2016. "Ending Inmate Isolation: Inside the Battle To Stop Solitary Confinement in America." https://medium.com/@gabriellecanon/ending-solitaryconfinement-bb4e0311e058 (March 9, 2018).

[10] Celermajer, Danielle and Kiran Grewal. 2013. " Preventing Human Rights Violations 'From the Inside': Enhancing the Role of Human Rights Education in Security Sector Reform." Journal of Human Rights Practice 5 (2): 243-266.

[11] Chicago Police Department. 2015. "The Facts About CPD's Homan Square Facility." https://dig.abclocal.go.com/wls/documents/Homan-Fact-Sheet.pdf (March 7, 2018).

[12] Chicago Police Department. 2011. 2011 Murder Analysis Report. https://home.chicagopolice.org/wp-content/uploads/2014/12/2011-MurderReport.pdf (January 12, 2018).

[13] Chiricos, Ted, Kelly Welch, and Marc Gertz. 2004. "Racial Typification of Crime and Support For Punitive Measures." Criminology 42 (2): 359-389. 
[14] Conrad, Courtney and Jacqueline DeMeritt. 2014. "Unintended Consequences: The Effect of Advocacy To End Torture On Empowerment Rights Violations." In Examining Torture: Empirical Studies of State Repression, eds. Tracy Lightcap and James P. Pfiffner. New York: Palgrave Macmillan, 159-184.

[15] Conrad, Courtney and Will H. Moore. 2010. 'What Stops the Torture?' American Journal of Political Science 54 (2): 459-476.

[16] Conroy, John. 2000. Unspeakable Acts, Ordinary People: The Dynamics of Torture. Berkeley: University of California.

[17] Conroy, John. 1990. "House of Screams" https://www.chicagoreader.com/chicago/houseof-screams/Content?oid=875107 (March 7, 2018).

[18] Conroy, John. 2005. "Tools of Torture." https://www.chicagoreader.com/chicago/toolsof-torture/Content?oid=917876 (March 8, 2018).

[19] Davenport, Christian and David Armstrong. 2004. "Democracy and the Violation of Human Rights: A Statistical Analysis From 1976-1996." American Journal of Political Science 48: 538-554.

[20] Davenport, Christian, David Armstrong, and Will H. Moore. 2007. "The Puzzle of Abu Ghraib: Are Democratic Institutions a Palliative or a Panacea?". https://whmooredotnet.files.wordpress.com/2014/07/the-puzzle-of-abu.pdf (March 10, 2018).

[21] Davenport, Christian, Will H. Moore, and David Armstrong. 2008. "Waterboarding In a Democracy? Torture, Political Threats and the Palliative Impact of Democratic Institutions." http:/ / citeseerx.ist.psu.edu/viewdoc/download?doi=10.1.1.453.6222\&rep=rep1\&type=pdf (March 10, 2018).

[22] Davenport, Christian and Sarah Soule. 2009. "Velvet Glove, Iron Fist, or Even Hand? Protest Policing In the United States." Mobilization: An International Quarterly 14 (1): $1-22$.

[23] Durkin, Thomas. 2016. "CPD's Homan Square Is No Black Site." https://chicago.suntimes.com/opinion/cpds-homan-square-is-no-cia-black-site/ (March 9, 2018).

[24] Federal Bureau of Investigation. 2016. Crime In the United States: Table 21 Arrests by Race and Ethnicity. https://ucr.fbi.gov/crime-in-the-u.s/2016/crime-in-theu.s.-2016/topic-pages/tables/table-21 (March 8, 2018). 
[25] Grimm, Andy. 2017. "Judge Tosses Confessions, Says Detective Gurvara Lied Under Oath." https://chicago.suntimes.com/chicago-politics/judge-tosses-confessionssays-detective-guevara-lied-under-oath/ (March 8, 2018).

[26] Hagedorn, John, Bart Kmiecik, Dick Simpson, Thomas J. Gradel, Melissa Mouritsen Zmuda, and David Sterrett. 2013. Crime, Corruption and Cover-ups In the Chicago Police Department. Chicago: University of Illinois In Chicago, Department of Political Science. https://pols.uic.edu/docs/default-source/chicago_politics/anticorruption_reports/policecorruption.pdf?sfvrsn=2 (March 9, 2018).

[27] Holmes, Malcolm D. 2000. "Minority Threat and Police Brutality: Determinants of Civil Rights Criminal Complaints In U.S. Municipalities." Criminology 38 (2): 343-368.

[28] Jacobs, David and Robert M. O’Brien. 1998. "The Determinants of Deadly Force: A Structural Analysis of Police Violence." American Journal of Sociology 103 (4): $837-862$.

[29] Jones, Anthony R. and George R. Fay. 2004. AR 15-6 Investigation of The Abu Ghraib Prison and the 205th Military Police Brigade / AR 15-6 Investigation of The Abu Ghraib Detention Facility and the 205th Military Police Brigade. In Torture and Truth, ed. Mark Dinner. New York: New York Review of Books, 403-579.

[30] Lightcap, Tracy. 2011. The Politics of Torture. New York: Palgrave Macmillan.

[31] Lindberg, Richard. 2002. "The Babbling Burglar and the Summerdale Scandal: The Lessons of Police Malfeasance." http://www.richardlindberg.net/articles/summerdale.html (March 9, 2018).

[32] MacDonald, John M., Robert J. Kaminski, Geoffrey P. Alpert, and Abraham N. Tannenbaum. 2001. "The Temporal Relationship Between Police Killings of Civilians and Criminal Homicide: A Refined Version of the Danger-Perception Theory." Crime and Delinquency 47 (2): 155-172.

[33] Marshall, T. H. 1965. Class, Citizenship, and Social Development. Garden City, NY: Doubleday Anchor.

[34] McCoy, Alfred W. 2007. A Question of Torture: CIA Interrogation From the Cold War To the War on Terror. New York: Metropolitan Books.

[35] Miller, Peter, Paul Gornke, and Darius Rejali. 2014. "Torture and Public Opinion: The Partisan Dimension." In Examining Torture: Empirical Studies of State Repression, eds. Tracy Lightcap and James P. Pfiffner. New York: Palgrave Macmillan, 11-42. 
[36] Office of Professional Standards. Chicago Police Department. "Special Project Conclusion Reports (The Burge Investigation)." http://peopleslawoffice.com/wpcontent/uploads/2012/02/Goldston-Report-with-11.2.90-Coversheet.pdf (March 8, 2018).

[37] Panwala, Asia S. 2002. "The Failure of Local and Federal Prosecutors To Curb Police Brutality." Fordham Urban Law Journal 30 (2): 639-662.

[38] People's Law Office. 2007. "118 Documented Burge Area 2 and Area 3 Victims." http://peopleslawoffice.com/wp-content/uploads/2014/01/1.6.14.-DocumentedTortureSurvivorsunderBurge.pdf (March 9, 2018).

[39] Rejali, Darius. 2006. "Containing Torture: How Torture Begets Even More Torture." http://www.slate.com/articles/news_and_politics/jurisprudence/2006/10 /containing_torture.html (Marh 4, 2018).

[40] Rejali, Darius. 2007. Torture and Democracy. Princeton: Princeton University Press.

[41] Romanyshyn, Yuliana. 2017. "Chicago Homicide Rate Compared: Most Big Cities Don't Recover From Spikes Right Away." Chicago Tribune, September 26.

[42] Sanders, Francine J. 2016. "A Former Investigator of Police Conduct On the Questions She Never Asked." https://www.chicagoreader.com/chicago/police-departmentcpd-excessive-force-internal-affairs/Content?oid=10986389 (March 7, 2018).

[43] Schmidt, Randall M. and John T. Furlow. 2005. AR-15 Final Report: Investigation Into FBI Allegations of Detainee Abuse at Guantanamo Bay, Cuba Detention Facility. https://www.thetorturedatabase.org/files/foia_subsite/pdfs/schmidt_furlow_report.pdf (March 8, 2018).

[44] Smith, Brad W. and Malcolm D. Holmes. 2014. "Police Use of Excessive Force In Minority Communities: A Test of the Minority Threat, Place, and Community Access Hypotheses." Social Problems 61 (1): 83-104.

[45] Solzhenitsyn, Aleksandr. 1973. The Gulag Archipelago: 1918-1956: An Experiment in Literary Investigation, I. New York: Harper and Row.

[46] Spinner, Jackie. 2015. "The Guardian's Homan Square Story Was Huge On the Internet - But Not In Chicago Media." https://www.cjr.org/united_states_projectguardian_homan_square_ chicago_media.php (March 9, 2018). 
[47] Stafford, Zach and Spencer Ackerman. 2016. "A Death In Police Custody: What Really Happened At Chicago's Homan Square?" https://www.theguardian.com/usnews/2016/apr/12/homan-square-chicago-police-files-custody-death-jaime-galvan (March 10, 2018).

[48] Taylor, G. F. 2014. "The Chicago Police Torture Scandal: A Legal and Political History." CUNY Law Review 17: 329-381.

[49] United Nations. 1984. Convention Against Torture and Other Cruel, Inhumane, Or Degrading Treatment Or Punishment. http://www.ohchr.org/EN/ProfessionalInterest/Pages/CAT.aspx (March 7, 2018).

[50] U. S. Congress. Senate. Senate Select Committee On Intelligence. 2014. Committee Study of the Central Intelligence Agency's Detention and Interrogation Program. Washington: GPO.

[51] U. S. Department of Justice. Civil Rights Division. United States District Attorney's Office, Northern District of Illinois. 2017. Investigation of the Chicago Police Department. https://www.justice.gov/opa/file/925846/download (March 8, 2018). 
Figure 1:

\section{The Development of Torture in Police/Order Agencies}

Experience with tortuous interrogations

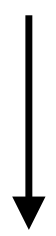

Perceived threat to police/order agency mission

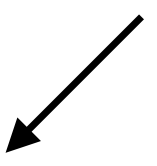

Police/order agency

with strong institutional controls

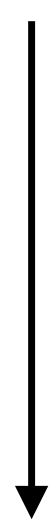

Official procedures

followed; torture

does not reappear

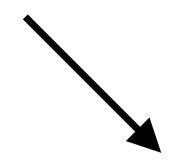

Police/order agency

without strong institutional controls
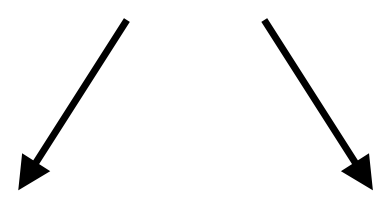

"Bureaucrats"

“Combatants'
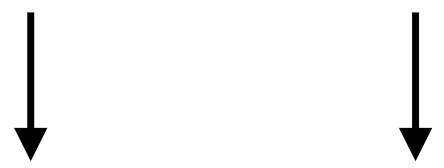

Official procedures Informal institutions

followed; torture created; torture

does not reappear reappears 
Figure 2: Total Murders in Chicago: 1957 - 2018

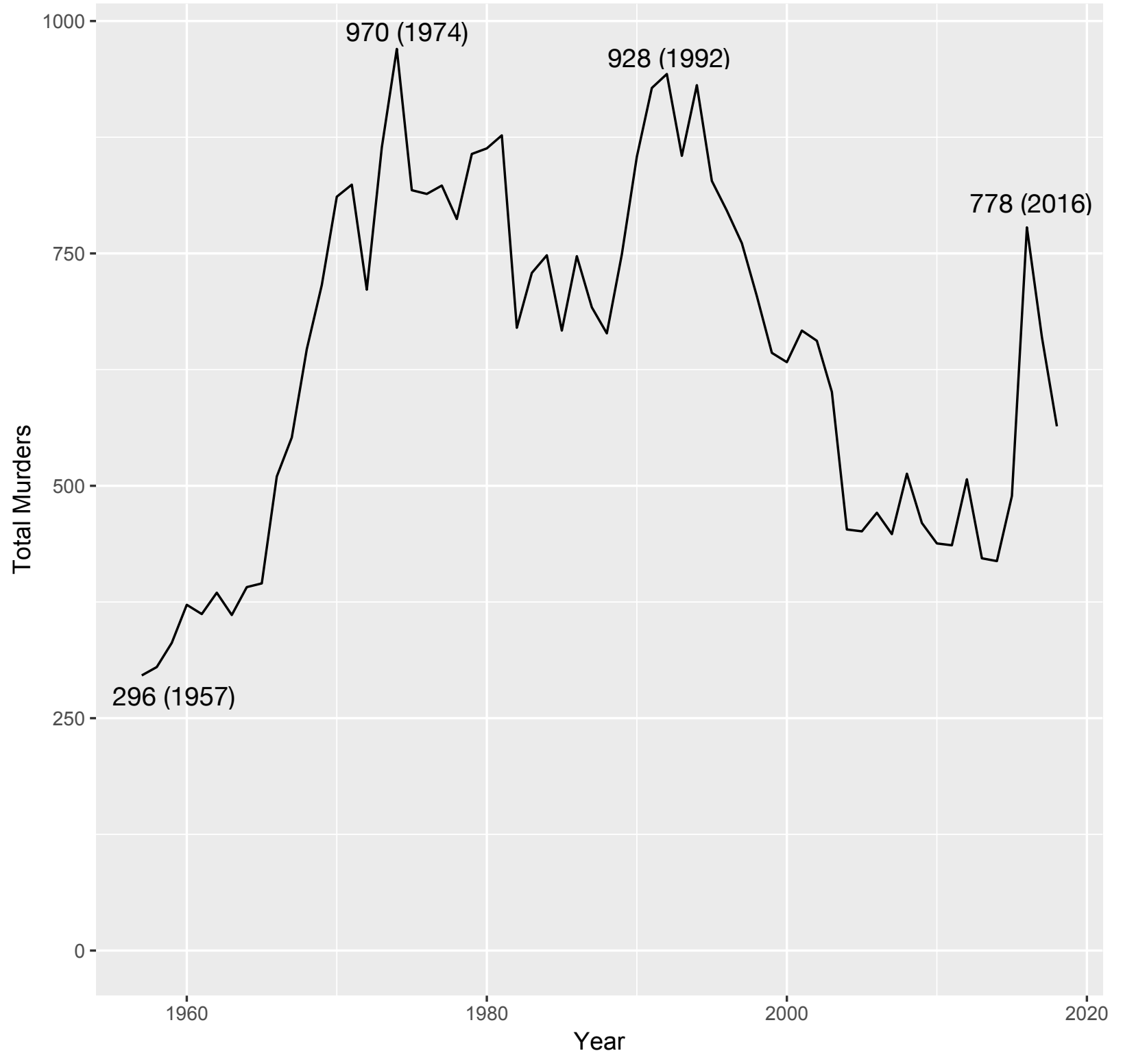


Table 1: Reform efforts for the Chicago Police Department

\begin{tabular}{|c|c|c|}
\hline Precipitating event & $\begin{array}{l}\text { Reform } \\
\text { Effort }\end{array}$ & Retrenchment \\
\hline $\begin{array}{l}\text { Summerdale } \\
\text { burglary ring (1960) }\end{array}$ & $\begin{array}{l}\text { Police Board established } \\
\text { Superintendent created }\end{array}$ & $\begin{array}{l}\text { Power of Superintendent } \\
\text { increased }\end{array}$ \\
\hline $\begin{array}{l}\text { Complaints increase, } \\
\text { racial tension (1966) }\end{array}$ & $\begin{array}{l}\text { Internal Investigations Division } \\
\text { (IID) examined; Citizens Committee } \\
\text { on Community Relations established }\end{array}$ & $\begin{array}{l}\text { No action taken on } \\
\text { complaints, procedures, IID } \\
\text { reorganized }\end{array}$ \\
\hline $\begin{array}{l}\text { Police riot at the Democratic } \\
\text { National Convention (1968) }\end{array}$ & No action taken & No action taken \\
\hline $\begin{array}{l}\text { Black Panther "Shootout" } \\
\text { (1969) }\end{array}$ & $\begin{array}{l}\text { Internal Affairs Division (IAD) } \\
\text { established; Commission on } \\
\text { Human Relations reviews IAD }\end{array}$ & No action taken \\
\hline $\begin{array}{l}\text { Complaints increase, } \\
\text { Knoohuizen Report (1972) } \\
\text { continuing racial tension }\end{array}$ & $\begin{array}{l}\text { Office of Professional Standards } \\
\text { (OPS) created }\end{array}$ & $\begin{array}{l}\text { No public hearings, } \\
\text { No subpoena powers } \\
\text { for OPS }\end{array}$ \\
\hline $\begin{array}{l}\text { "Marquette 10" drug } \\
\text { protection ring (1982) }\end{array}$ & No action taken & $\begin{array}{l}\text { All officers tried, } \\
\text { convicted, no administrative } \\
\text { action }\end{array}$ \\
\hline $\begin{array}{l}\text { Jon Burge/Area } 2 \\
\text { torturous interrogations } \\
(1980-1989)\end{array}$ & No action taken & $\begin{array}{l}5 \text { year limitation on OPS } \\
\text { administrative proceedings, } \\
\text { Burge fired (1993) } \\
\text { Burge convicted on unrelated } \\
\text { federal charges }(2010)\end{array}$ \\
\hline $\begin{array}{l}\text { "Austin 7" extortion } \\
\text { ring (1996) }\end{array}$ & $\begin{array}{l}\text { Mayor's Commission on } \\
\text { Police Integrity (1998) }\end{array}$ & $\begin{array}{l}\text { All officers tried, } \\
\text { convicted; department urged } \\
\text { to monitor civilan complaints }\end{array}$ \\
\hline $\begin{array}{l}\text { Special Operations } \\
\text { Section ring (2007) } \\
\text { Futterman Report (2006) }\end{array}$ & $\begin{array}{l}\text { Independent Police Review } \\
\text { Authority (IPRA) created, OPS } \\
\text { abolished }\end{array}$ & $\begin{array}{l}6 \text { of } 10 \text { officers tried, } \\
\text { convicted }\end{array}$ \\
\hline $\begin{array}{l}\text { Chicago Justice Project } \\
\text { Report (2009) }\end{array}$ & No action taken & No action taken \\
\hline
\end{tabular}


Richard Zuley/Holman

Square torturous

interrogations (1995 -

2015)

Department of Justice

Report (2017)
No action taken

Police Accountability Task Force (2016), Civilian Office of Police Accountability (COPA) (2017), IPRA abolished, Community Policing Advisory Panel (2017)
No action taken

Task Force recommendations adopted, mandated release of police videos/materials on abuse cases, "body cameras" mandated.

Sources: Conroy 1990, Conroy 2000, Hageborn et al. 2013, Ackerman 2015a, 2015b,

Department of Justice 2017, Kush 2004. 
Figure 3: Total Murders in Chicago 1957-2018 and Boston 1960-2014

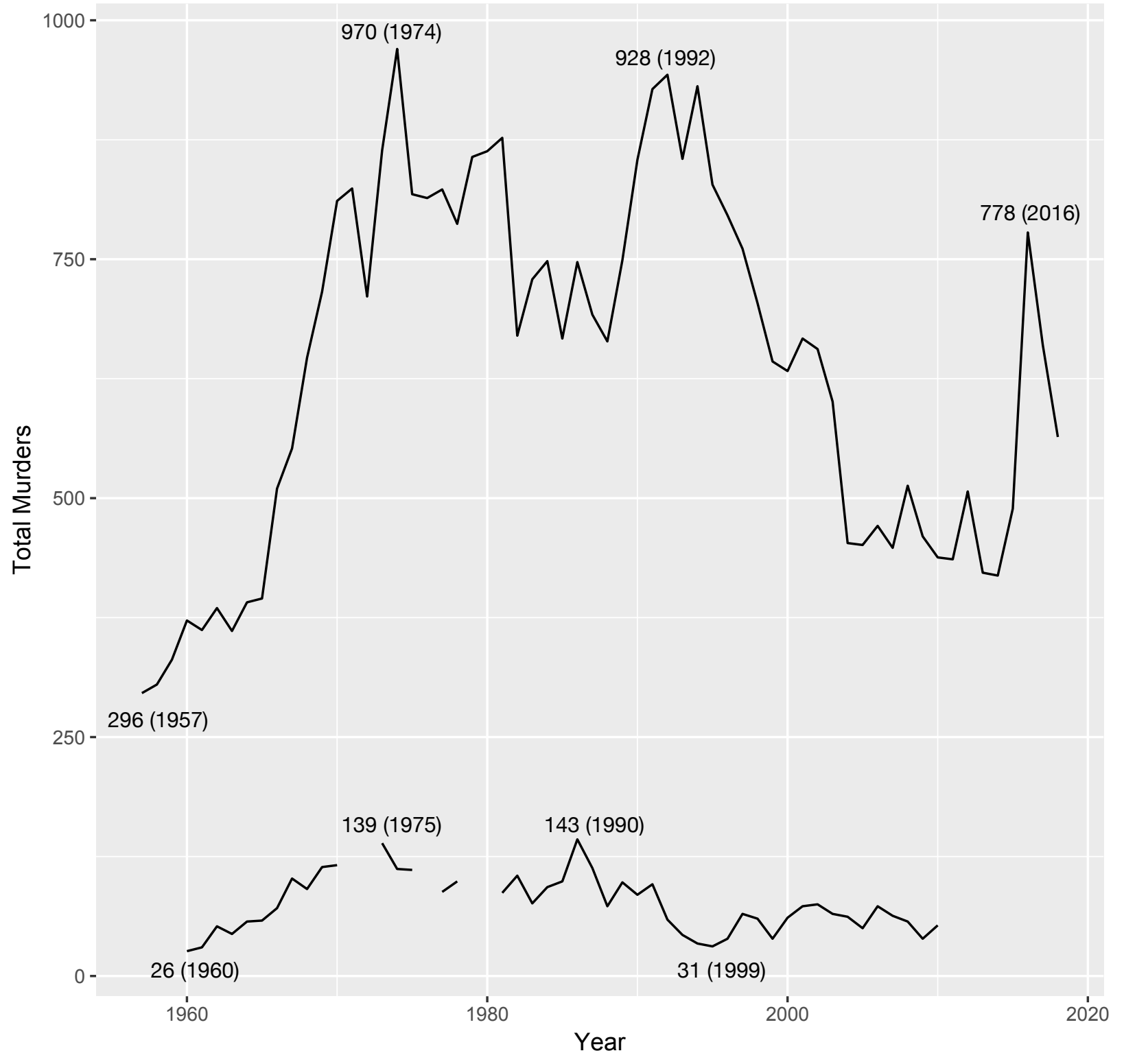

Sources: 
Table 2: Reform efforts for the Boston Police Department

\begin{tabular}{|c|c|c|}
\hline Precipitating event & $\begin{array}{l}\text { Reform } \\
\text { Effort }\end{array}$ & Retrenchment \\
\hline $\begin{array}{l}\text { Biography of a } \\
\text { Bookie Joint CBS (1961) }\end{array}$ & $\begin{array}{l}\text { Appointment of Commissioner } \\
\text { to Mayor of Boston } \\
\text { Quinn Tamm Report (1962) }\end{array}$ & $\begin{array}{l}\text { Commissioner replaced } \\
\text { Officers not dismissed }\end{array}$ \\
\hline $\begin{array}{l}\text { Towing contract scandal } \\
\text { (1963) }\end{array}$ & $\begin{array}{l}\text { All police towing halted } \\
\text { temporarily, new contract } \\
\text { procedures put in place }\end{array}$ & Commissioner cleared \\
\hline $\begin{array}{l}\text { South Boston Riots } \\
\text { (1974) }\end{array}$ & $\begin{array}{l}\text { Community Disorders Unit } \\
\text { established }\end{array}$ & No action taken \\
\hline $\begin{array}{l}\text { FBI investigation of } \\
\text { payoffs (1986) }\end{array}$ & No action taken & All officers tried, convicted, \\
\hline $\begin{array}{l}\text { Charles Stuart case (1990) } \\
\text { Racial unrest in Roxbury } \\
\text { over withdrawn accusation, } \\
\text { alleged search excesses, } \\
\text { coercive interrogations }\end{array}$ & $\begin{array}{l}\text { Shannon Report } \\
\text { St. Clair Report } \\
\text { Hennessey Report }\end{array}$ & $\begin{array}{l}\text { Commissioner resigns, } \\
\text { Internal Affairs Department } \\
\text { reorganized, 4th amendment } \\
\text { training mandated, no action } \\
\text { taken on alleged coercive } \\
\text { interrogations }\end{array}$ \\
\hline
\end{tabular}

Sources: Smith 1974 (The Tarnished Badge, NY:Arno), Doyle, James S. (March 28, 1963).

Shannon Report $1990<$ https://ia600305.us.archive.org/25/items/reportofattorney02mass_0/

reportofattorney02mass_0.pdf $>$, Scott Michels Operation ceasefire $<$ https://

www.retroreport.org/transcript/operation-ceasefire/> Hennessey Report $1990<\underline{\mathrm{https}: / /}$

archive.org/stream/bostonpolicedepa00bost/bostonpolicedepa00bost_djvu.txt $>$, St. Clair Report

$1992<\underline{\text { http://vault.blackstonian.org/wp-content/uploads/2016/10/St.-Clair-Commission- }}$

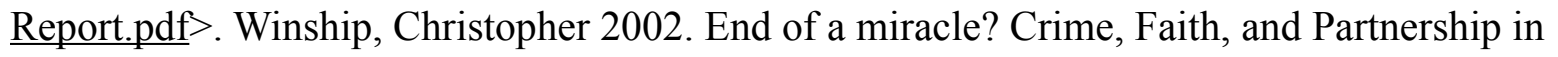

Boston. $<\underline{\text { https://static1.squarespace.com/static/5413254ce4b05a9f6b772941/t/ }}$ 
5485fa94e4b0afb70c5a6842/1418066580801/End_of_a_Miracle.pdf $>$ Fox Butterfield. 1986.

FBI Inquiry into Boston Police Disclosed $<$ https://www.nytimes.com/1986/10/23/us/fbi-inquiryin-boston-police-disclosed.html> 